Third Issue, september, 2020, Vol. 4

\title{
Effect of Intellectual Capital on
}

${ }^{1}$ Dr. Mawaheb Abdel-Aziz Ismail

Accounting Lecturer

Department of Accounting

Alexandria University
Firm Value and Financial Performance: An Empirical Study on

Companies Listed on Egyptian

Stock Exchange

\section{Abstract}

The paper examines the relation between firms' intellectual capital and firm's value and financial performance for a sample of firms listed on the Egyptian Stock Exchange during the period from 2000 through 2014. I predict that the level of investment in intellectual capital has a positive impact on firm's value, and firm's liquidity and activity levels as measures of financial performance. Results reveal that the level of intellectual capital has a positive impact on firm's value measured by Tobin's Q. Firm's liquidity is not significantly affected by level of intellectual capital. Moreover, the level of intellectual capital has a significant impact on firm's activity, on the aggregate level. However, the intensity of intellectual capital investment has no significant impact on firm's activity level.

Keywords: Intellectual capital, Tobin's Q, Current Ratio, Total assets turn over, intensity of intangible assets.

E.mail: ${ }^{1}:$ mawaheb.ismail@gmail.com 


\section{تأثير رأسمال المعرفي على قيمة المنشأة وأدائها المالي: دراسة تطبيقية على الثركات المقيدة بالبورصة المصرية}

\section{ملخص البحث}

يتتاول البحث دراسة العلاقة بين رأسمال المعرفي وقيمة المنشأة وأدائها المالي، وذلك لعينة من

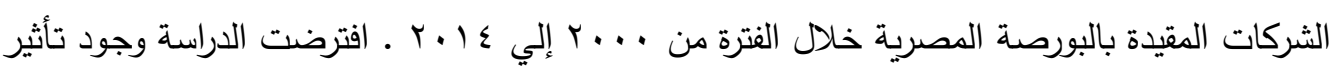
إيجابي لرأسمال المعرفي على قيمة المنشأة، ومستوى السيولة و النشاط كمقاييس للأداء المالي.

أوضحت النتائج أن رأسمال المعرفي لـه تأثير إيجابي معنوي على قيمة المنشأة، وكذلك مستوى النشاط. أما مستوى السيولة، فلم يتأثر برأسمال المعرفي. الكلمات المفتاحية: رأسمال المعرفي، قيمة المنشأة، مستوى السيولة، مستوى النشاط. 


\section{1- INTRODUCTION}

Over the last two decades, there has been a dramatic growth in intellectual capital investments over total firm's investment. Researchers name such growth as shifting towards "knowledge economy". Previous studies, such as Marrano et al. (2009), and Baldwin et al. (2012), attributed productivity growth at macro \& firm level to intensive investment in intellectual capital. The dramatically increase in the share of intellectual asset over the total firm's investment is believed to be the main reason for the evidenced huge difference between companies' book value and market value.

The topic of intellectual capital has been extensively discussed by researchers since the early 1990s. The literature uses the terms "intellectual capital", "intangible assets", "intellectual asset", and "knowledge asset" interchangeably providing a wide range of definitions. The agreed upon features of all intangible assets, as prescribed by IAS 38, are that intangibles are identifiable non-monetary legally protected assets lacking physical substance, providing future economic benefits, and obtained from past activities such as research and development, training, contractual agreement.

Some researchers (e.g., Edvinsson and Malone 1997, Stewart 1997, and Mouritsen el al. 2001) perceive intellectual capital as the difference between the firm's market value and its book value. In accounting terms, this is named as "Goodwill". Thus, intellectual capital is the intangible value of a business. This includes: human capital, structural capital, and relational capital. Human capital represents the value created by employees' skills, know-how, expertise, and competence (Bontis 2001). Structural capital refers to the non-physical infrastructure, processes, and databases of the organization that enable human capital to function. Relational capital denotes such elements as customer relationships, supplier relationships, trademarks, and trade names.

Prior literature highly documented the intense investment in intellectual capital over the last twenty years. Kaplan and Norton (2004) compared the book 
value of total assets to market value of US firms, and found that intangible (intellectual) assets increased from about 40\% in 1982 to almost 70\% of firm's market value. As researchers reported, for high-tech companies, the contribution of intangible assets in output growth was more than 6 times the contribution of tangible assets (Fukao et al. 2009, and Clayton et al. 2009). This is prevalent in both developed as well as developing countries (Hao et al. 2009, and Corrado et al. 2009). Moreover, and according to Corrado and Hulten (2014), the share of intellectual capital investment reached over $14 \%$ of US gross domestic product in 2010.

For many reasons discussing the issue of intellectual capital remain complex and provide contradictory conclusions. Investments in intangibles are perceived to be more risky compared to tangible and financial assets. This is attributable to the high uncertainty in the value of intangibles, that is, the extent to which newly ideas or technology would contribute to future profits. Also, the issue of property rights adds to the inherent high risk of intellectual capital, where IAS 38 identifies intangibles as separable assets that can be sold, transferred, licensed, rent, or exchanged either individually or aggregately with a related contract. The high risk and difficulty of defining and enforcing property rights are well documented by research (Lev 2001, Cabral 2000, Cohen et al. 2000). In addition, lack of active and transparent markets for intangible assets makes it more difficult for analysts to assess future earnings for intangibles-intensive firms.

The credibility of financial statements for high-tech firms remains at question. The major aim of any firm is to enhance its company value in order to increase shareholders' wealth and serve the interests of other stakeholders. Firm value, as reflected in company's market price, is highly deviated from book values. It is argued that such deviation indicates that physical and financial assets presented in the company's balance sheet are calculated at less than $20 \%$ of its actual value. The increasing gap between firm's book value and its market value prompted researchers to discover whether intellectual capital is significant factor in increasing firm's value, and whether such value is reflected in firm's financial 
statements.

Like many countries, the Egyptian market evidenced major changes over the last twenty years. The early 2000s witnessed a fast growing role of private sector and a shift towards knowledge economy. Many companies have emerged depending mainly on intangible assets, with physical and financial assets being marginal. The investment composition is gradually shifting from tangible to intangible assets. Yet, we are still far behind. Investment in intellectual capital in many countries represents at least 10\% of GDP (OECD 2013), whereas in Egypt investment share of intellectual capital is about 1\% of GDP. Investment composition of intangibles, as analyzed by Chen (2018), is also remarkable. Share of Research and Development (R\&D) is almost negligible, total investment in intangible is composed mainly of brand equity.

Motivated by the well-established literature documenting the impact on intangibles on corporate value, this research aims to contribute to the understanding of this issue by studying the effect of intellectual capital on firms' value and financial performance, mainly liquidity and activity, for a sample of listed Egyptian companies.

The paper further investigates the effect of intangibles intensity on firm value and performance. The results reveal that investment in intellectual capital has a significant impact on firm value, measured by Tobin's $Q$. This result has been proven valid both for the full sample and two sub-samples; high-intellectual capital firms and low- intellectual capital firms. Moreover, evidence does not lend credence to the existence of any impact of intellectual capital on firms' liquidity, measured by current ratio. This rejection is related to both aggregate and partial levels of analysis. Also, findings support the significant impact of intellectual capital on firms' activity, measured by total assets turn over. This has been proven true only for full sample, but not for sub-samples.

The paper contributes to the literature on intellectual assets through providing evidence from Egypt as one of the emerging economies. It complements previous research on intangibles and its effect on firms' value and performance. 
Despite the availability of several studies documenting growth and effect of intellectual assets in various contexts, the existing literature provides little evidence of the effect of such topic on value and performance of firms operating in Egypt.

The remainder of the paper is organized as follows: Section (2) presents literature review and hypotheses development. Section (3) describes the sample and research design. Empirical results are presented in Section (4). A summary of the findings and concluding remarks appears in Section (5).

\section{2- LITERATURE REVIEW AND HYPOTHESES DEVELOPMENT}

\section{2-1 Literature Review}

Literature provides many terminologies and definitions for intangible assets. Academic researchers, international organizations, and regulatory bodies define and classify intangibles in different ways. According to FASB, intangible assets incorporate:

1- Marketing-related intangibles; including trademarks, brand names, internet domain, and newspaper mastheads.

2- Customer-related intangibles; including customer lists and contracts, and order or production backlog.

3- Artistic-related intangibles; including plays, literary and musical works, audiovisual production, and television programs.

4- Contract-related intangibles; including licenses, construction permits, and franchise agreements.

5- Technology-related intangibles; including patents and trade secrets.

The European Union's MERITU project perceives intellectual assets entail Human capital, Structural capital, and Relational capital. The OECD (1992) classifies intangibles to include $\mathrm{R} \& \mathrm{D}$, patents, licenses, and enabling intangible investments (worker training, information structure and organizational structure). 
Researchers (e.g., Edvinsson 1997, and Lev 2001) agreed that intangibles are resources that add value to the business, and that exist in addition to working capital and tangible assets, and are contributors to the earnings power of the company. Intellectual capital is the result of the network effect, and cannot stand by itself, and therefore benefits derived from the use of intangibles are somehow difficult to be reliably measured.

The measurement and reporting of intangibles have been and still a highly controversial accounting issue. Despite the contribution of intellectual capital for productivity at firm level, and economic growth at macro level, measurement and reporting of intangibles are accompanied by some obstacles.

First, different valuation approaches are applied to measure intellectual capital (Yallwe and Buscemi 2014):

1- Direct intellectual capital method; where firms estimate the monetary value individually or aggregately.

2- Market capitalization method; based on recording the difference between market value and book value of company's total investment.

3- Return on asset method; based on scaling company average earnings by average cost of capital.

4- Scorecard method; based on identifying the various components and determining indicators and indices.

5- Expenditure-based approach; where firms are assumed to invest in intangibles until the discounted present value of the future expected income stream equals to the cost of producing the marginal asset (Corrado et al 2005).

6- Value added intellectual coefficient VAIC; measures how much new value has been created per invested monetary unit of resources. VAIC is composed of human capital, structural capital, and capital employed (Pulic 2000a).

Second, according to accounting standards, most of the investments in intangibles are treated as period expenses regardless of their future benefits. Firms are reluctant to disclose details regarding intellectual assets due to the competitive environment. 
Most intellectual assets are not recognized in financial statements, and accounting standards do not require firms to report separate performance measures for intellectual capital. Conservative accounting rules require firms to recognize expenses as soon as possible when they are uncertain about the future. Such inclusion of more expense makes companies report less profit than what they actually earned (Lev 2003). The recognition and reporting of more expenses might bring great difference between the market and book value of the company. Moreover, the inconsistent treatment of externally acquired intangibles versus internally created intangibles adds to the complexity of such issue making it unresolved long lasting accounting topic.

Third, investment in intellectual capital entails financing constraints. Masayuki (2012) used Japanese firm level data to measure the sensitivity of investment to cash flow by the type of asset, and concluded that investment in intangible assets are strongly sensitive than investment in tangible assets.

The issue of intangible assets has been the concern of a bulk of studies addressing different dimensions. One stream of studies focuses on analyzing the impact of intangibles on the accuracy of analysts' forecasts. Barth et al. (2001) argue that the increasing importance of intangible assets and the absence of explicit information about the contribution of intangibles to firm value imply strong market incentives for analysts to incur private search costs to discover the predicted value of intangibles for high-tech firms. It was found that analysts' coverage and effort are greater for firms with more intangible assets. Gu and Wang (2005) explore that intellectual assets are associated with more complex information compared to tangible and financial assets due to the high uncertainty in the value of intangibles, along with lack of reliable value estimates for most intangibles. Evidence supports a positive association between analysts' forecast error and firm's investment in intellectual capital. Therefore, the information complexity of intellectual capital increases the difficulty of forecasting earnings of intangiblesintensive firms. 
Another stream of studies was devoted to evaluate and criticize the accounting treatment for intangibles which has been subject to continuing controversy. Choi et al. (2000) emphasized the idea that financial statements fail to reflect differences in the uncertainty of future economic benefits and costs associated with different types of assets. Assets appearing on the financial position statement are not differentially weighted according to their different levels of uncertainty.

This paper belongs to a wide domain of studies devoted to explore the impact of intellectual capital on firm value and financial performance. Chen et al. (2005) employed a large sample of Taiwanese listed companies, and used VAIC as a measure of intellectual capital in order to assess such relation. Findings underlined the importance of intellectual assets in enhancing firm profitability and revenue growth. Also, investors place more value for companies with better intellectual capital efficiency. Using the same measurement tool and context, Shiu (2006b) reached a positive significant correlation between intellectual capital and both profitability and market valuation. Another setting, Singapore, was examined by Tan et al. (2007) which used data from 150 companies listed on Singapore Stock Exchange. It concluded that intangibles are correlated with company's current and future performance, and such correlation differs by industry. Ting and Lean (2009) focused on financial institutions in Malaysia and reached a positive relationship between intellectual capital and profitability. In line with prior findings, Appuhami (2007), Wang (2008 and 2013), Chang (2013), and Pucci et al. (2013), all provide empirical evidence supporting the positive impact of intellectual capital on firm value and different performance measures.

On the other hand, a number of studies fail to support intellectual capital's impact on corporate valuation and performance. Firer and Williams (2003) used VAIC as a measure of intellectual assets, and data from South Africa business sectors. Empirical evidence did not find any significant association between VAIC and firms' market value, profitability, or productivity. Maditinos et al. (2011) employed data from Greek companies listed in Athens Stock Exchange to inves- 
tigate the prevalent assumption. Results fail to support the claim that intellectual capital is positively linked to performance, although it positively affects market value.

\section{2-2 Hypotheses Development}

Firm value is the core of corporate finance, and company's main objective is to maximize its value through best utilization of its resources, whether tangible or intangible assets. The impact of intellectual assets on firm's value has been a rich area of research. While intellectual capital is company's assets whose growth should raise firm's value, empirical results show contradictory results concerning this relation. Some studies found positive correlation between intellectual capital and company value, while others did not find any relationship.

Studies supporting the positive relation between intellectual capital and firm value employ different measures of assessing intellectual capital. Chen et al (2005) suggest that investors place higher value on companies with better intellectual capital efficiency. Wang (2008) use different measures to assess firm's value and reached that it is positively correlated with intangibles. Same results were reached by Pucci et al (2013) and Wang (2013).

Others studies did not find any relationship between intangibles and firm's value. For example, Ferraro and Veltri (2011) used 524 firm-year observations of Italian listed companies and concluded that Italian market does not rely on intellectual capital information in valuing firms. Also, Mehralian et al. (2012) examined the pharmaceutical companies listed in the Iranian Stock Exchange and reached that intellectual components are not correlated to market valuation, only to profitability.

Motivated by the above mixing results, our first hypothesis can be developed as follows: 


\section{H1: The level of firm's intellectual assets has a positive impact on firm's value.}

The rise of intellectual capital in size and contribution to firm growth creates an interesting research area for academics. Literature has been concerned with analyzing the effect of investment in intellectual capital on financial performance. The increasing gap observed between market value and book value of many companies has drawn attention towards investigating the value missing in financial statements. Many researchers, for example Chen et al. (2005), Yang and Lin (2009), and others, consider intellectual assets the hidden value that is omitted from financial statements and leads firms to gain competitive advantage and earn superior earnings.

As indicated in the literature review, a number of previous studies examined the impact of intellectual capital on firm's financial performance; however, empirical evidence is inconclusive and far from reaching consensus.

On the one hand, Riahi-Belkaoui (2003), using data from US multinational firms, and Bontis et al. (2000), using data from Malaysian firms, support a positive relationship between intellectual assets and financial performance indicators. Same was reached by Chen et al. (2005) which indicate a positive impact of intellectual capital, measured by value added intellectual coefficient VAIC, on firm's profitability. Moreover, they proved that this coefficient can be used to assess future financial performance.

On the other hand, Firer and Williams (2003) used intangibles-intensive firms from South Africa and showed that corporate performance is not correlated with intangibles. Also, Maditinos et al. (2011) examined this relationship in the context of Greek companies and reached that intellectual capital is hardly linked to financial performance.

The researcher believes that the reason for inconclusive results regarding the impact of intangibles on financial performance is the difference in contexts, measurement tools, and study periods. 
Since financial performance has many dimensions and indicators, I specify liquidity and activity levels to denote firm's financial performance. In order to test the impact of intangibles on financial performance, my second and third hypotheses can be illustrated as follows:

H2: The level of firm's intellectual assets is positively related to firm's financial performance measured by liquidity level.

H3: The level of firm's intellectual assets is positively related to firm's financial performance measured by activity level.

\section{3 -RESEARCH DESIGN}

This section presents sample selection, along with the empirical models employed.

\section{3-1 Data and Sample Selection}

The initial study sample consists of the most active firms continuously listed on the Egyptian Stock Exchange included in EGX 100 during the period of 2000-2014. The following companies were excluded:

1- Companies in the financial industry and utility industry are excluded since they face different regulatory environments than those of other companies.

2- Companies with missing data in at least one variable.

The exclusion criteria ended up with a final sample of 30 firms distributed over six manufacturing sectors: Food and Beverage, Chemicals, Construction and materials, Healthcare and Pharmaceuticals, Industrial goods and services, and Technology. Our final sample represents 450 firm-year observations. Study Period, extending from 2000 through 2014, is most appropriate to fulfill our research objective. This is because the Egyptian stock market during that period has witnessed major differences between book value and market value of firms' equity. Moreover, this period, and the coming period indeed, can be perceived 
an era of intellectual capital where investing in innovative and technology-based projects is highly targeted (Ismail 2011).

\section{3-2 Measurement of Study Variables \\ 3-2-1 Independent Variable: Intellectual Assets}

$\mathrm{IA}_{\mathrm{it}}$ is the level of firm's intellectual assets measured using market capitalization method as the difference between market value of equity MVE and the book value of equity BVE for each firm-year (Edvinsson and Malone 1997, and Mouritsen el al. 2001).

As mentioned before, there are a number of alternative approaches that have been developed in the literature to assess intellectual assets. Some studies, for example Barron et al. (2002), measure intangibles as the summation of advertising expenses, $\mathrm{R} \& \mathrm{D}$, and intangible assets figure in the balance sheet. Other papers (Corrado et al. 2005, 2009, and Fukao et al. 2009) assess intangibles through R\&D expenses, organizational capital (\% of manager's labor compensation), and brand equity (\% of advertising expenses). Moreover, Value Added Intellectual Coefficient (VAIC) has been used by many researchers to estimate intellectual assets through its three components: human, structural, and capital employed (Pulic 2000a, Firer and Williams 2003, Wang 2008, and Chen et al. 2005).

The reason for choosing market capitalization method is the applicability and data availability, where R\&D expenses were totally missed in most of our sample firms' financial statements.

\section{3-2-2 Dependent Variables}

\section{3-2-2-1 Firm Value}

Firm value, is measured using Tobin's $\mathrm{Q}=\mathrm{MV}$ of equity / BV of equity (Lang and Stulz 1994, and Gamayuni 2015). 


\section{3-2-2-2 Financial Performance}

Proxies for financial performance are:

1- Liquidity indicator; current ratio CR, current assets deflated by current liabilities (Kaoru et al. 2017, Aggelopoulos 2017).

2- Activity indicator; total assets turn over TATO, sales revenue scaled by total assets (Pucci et al. 2013, Gamayuni 2015).

\section{3-2-3 Control Variables}

In order to consider endogeneity effects and firm-specific characteristics, I include some control variables, widely used in literature, as follows: (Barron et al. 2002, Chalmers et al. 2012, and Alves and Martins 2014)

Size; measured as natural logarithm of firm's total assets.

Growth; measured as change in firm's sales revenue.

Leverage; measured as firm's total liability scaled by book value of equity.

Persistence; measured as change in firm's earnings figure.

\section{3-3 Empirical Models}

The first research hypothesis examines the correlation between firm's value and the level of firm's intangible assets. The following model illustrates the predicted relation as follows:

Tobin's $Q=\beta_{0}+\beta_{1} I_{i t}+\beta_{2}$ Size $_{i t}+\beta_{3}$ Growth $_{i t}+\beta_{4} \operatorname{Lev}_{\text {it }}+\beta_{5}$ Pers $_{i t}+$ C $_{1---}$ (1)

The second and third hypotheses illustrate the impact of intellectual capital on firm's financial performance. The following are the models expressing such relations:

$\mathrm{CR}_{\mathrm{it}}=\lambda_{0}+\lambda_{1} \mathrm{IA}_{\mathrm{it}}+\lambda_{2}$ Size $_{\mathrm{it}}+\lambda_{3}$ Growth $_{\mathrm{it}}+\lambda_{4}$ Lev $_{\mathrm{it}}+\lambda_{5}$ Pers $_{\mathrm{it}}+\mathrm{e}_{2^{-----}}(2)$

TATO $_{\text {it }}=\gamma_{0}+\gamma_{1} \mathrm{IA}_{\mathrm{it}}+\gamma_{2} \mathrm{Size}_{\mathrm{it}}+\gamma_{3}$ Growth $_{\mathrm{it}}+\gamma_{4} \mathrm{Lev}_{\mathrm{it}}+\gamma_{5}$ Pers $_{\mathrm{it}}+\mathrm{e}_{3----}$ (3) 


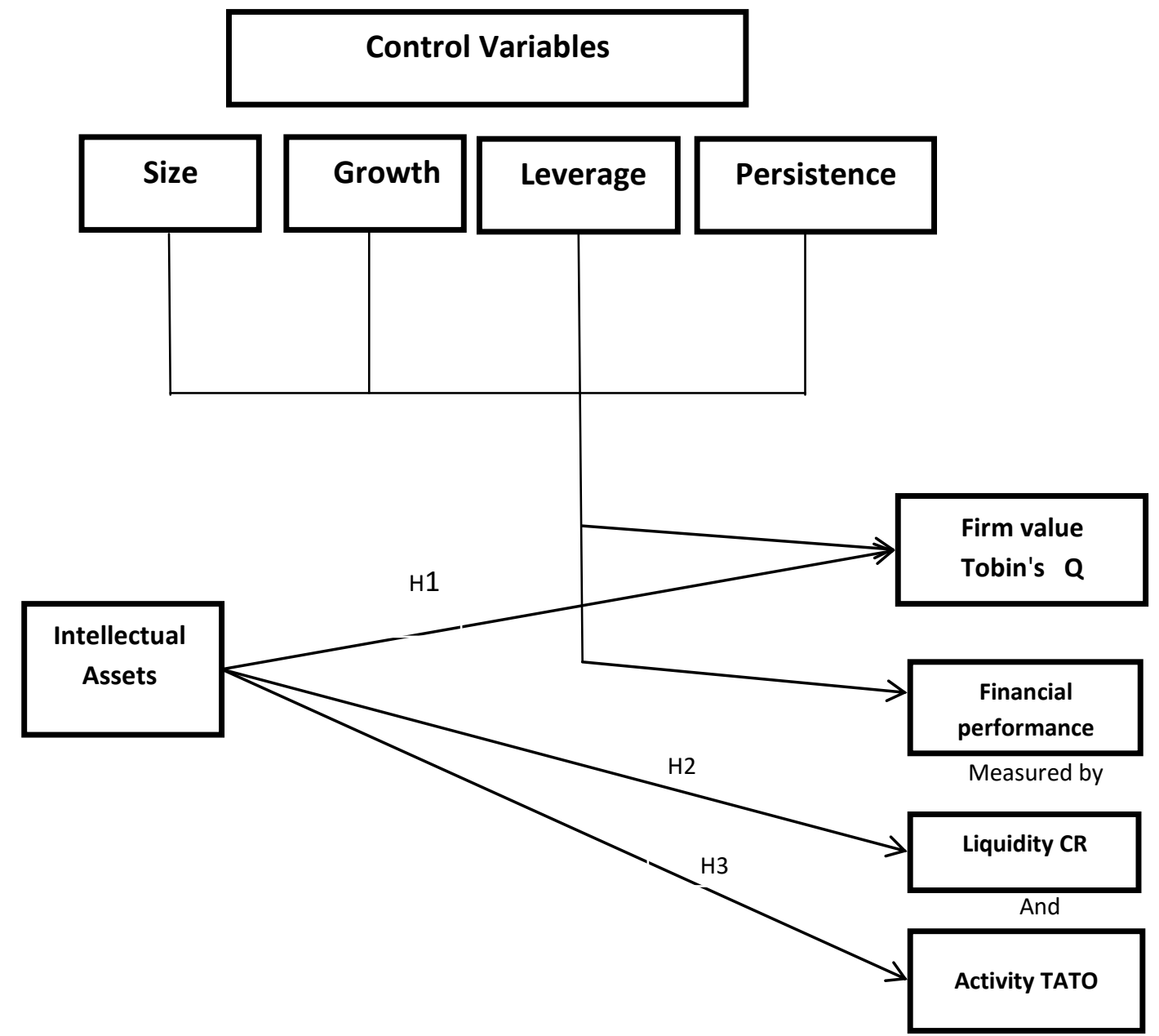

*prepared by the researcher 


\section{4 - RESULTS}

\section{4-1 Descriptive Statistics}

This section discusses descriptive statistics and outcomes of the fundamental and sensitivity analyses

\section{Table 1: Summary of Descriptive Statistics for Research Variables}

\begin{tabular}{|c|c|c|c|c|c|c|c|}
\hline Variables & Mean & Median & Std. Dev & Minimum & Maximum & $\mathbf{1}^{\text {st }}$ Quart & $3^{\text {rd }}$ Quart \\
\hline IA & 15.0083 & $\mathbf{0 . 5 8 7 2}$ & 57.3907 & -0.80002 & 693.082 & 0.1367 & 1.4838 \\
\hline CR & 2.60833 & 1.62019 & 3.31092 & 0.099748 & 32.07881 & 1.26942 & 2.390573 \\
\hline TATO & 0.77077 & 0.61732 & 0.69606 & 0.013285 & 5.524053 & 0.36979 & 0.92548 \\
\hline Tobin'sQ & 68.9717 & 3.15800 & 404.9418 & 0.056333 & 6732.8000 & 1.31724 & 7.828000 \\
\hline Size & 19.6913 & 19.9239 & 1.501792 & 16.32262 & 22.65552 & 18.33135 & 20.68986 \\
\hline Growth & -0.0091 & 0.0000 & 0.23647 & -4.94425 & 0.836337 & 0.000000 & 0.000000 \\
\hline Lev & 0.476529 & 0.08046 & 1.01182 & 0.00000 & 10.52439 & 0.004642 & 0.416922 \\
\hline Pers & -0.29193 & 0.03872 & 9.51686 & -193.096 & 40.92296 & -0.29633 & 0.272952 \\
\hline
\end{tabular}

Table (1) illustrates some important points. Intellectual assets (IA) constitute a large proportion of firm value. The differences between mean (15.008) and median (0.587) of IA suggest the existence of highly intellectual asset intensive firms alongside firms with low level of intellectual asset intensity in our sample. Intellectual asset shows high dispersion sited in a large standard deviation figure (57.39). For current ratio, the variable shows a low difference between mean (2.6) and median (1.6), and a low standard deviation (3.3), denoting a minor dispersion in current assets and current liabilities among sample firms. This is more obvious in analyzing total assets turn over (TATO). Tobin's Q shows the greatest standard deviation (404.9) and the largest differences between mean and median, and between minimum and maximum values. And so, firm value is the most dispersed variable among all. The four control variables show relatively low dispersion sited in low standard deviation values and small ranges.

In order to qualify my regression tests, I conduct the basic tests for normality (Skewness and Kurtosis values). Results indicate that the sample is normally distributed. For multicollinearity, I examine the variance inflation factors (VIFs) for predictors, and ensure a low values (less than 10) for all variables included in our 
regression models. Thus, I isolate the effects of both normality and multicollinearity in interpretation of regression outcomes. These tests were employed for the full sample in conducting the fundamental analysis, and each sub-sample in implementing the sensitivity analysis.

\section{Table 2:Correlation Matrix for Study Variables}

\begin{tabular}{|c|c|c|c|c|c|c|c|c|}
\hline Variables & IA & CR & TATO & Tobin's Q & Size & Growth & Lev & Pers \\
\hline IA & 1 & 0.067 & 0.084 & $0.903^{* *}$ & 0.022 & 0.001 & 0.083 & 0.008 \\
\hline CR & $0.184^{* *}$ & 1 & 0.082 & 0.027 & $-0.24^{* * *}$ & 0.03 & -0.054 & -0.59 \\
\hline TATO & 0.17 *** & $0.247^{* * *}$ & 1 & 0.005 & $-0.38^{* * *}$ & 0.018 & -0.072 & -0.014 \\
\hline Tobin'sQ & $0.94^{* * *}$ & $0.106^{*}$ & $0.15^{* * *}$ & 1 & 0.037 & 0.002 & $0.099^{* * *}$ & 0.007 \\
\hline Size & $0.105^{*}$ & $0.25^{* * *}$ & $-0.49^{* *}$ & $0.146^{* * *}$ & 1 & -0.04 & $0.126^{* * *}$ & 0.068 \\
\hline Growth & 0.31 & 0.061 & $0.42^{* * *}$ & 0.013 & $-0.255^{* *}$ & 1 & 0.017 & 0.005 \\
\hline Lev & $0.116^{*}$ & $-0.27^{* * *}$ & $-0.16^{* * *}$ & $0.2^{* *}$ & $0.367^{* * *}$ & 0.00 & 1 & 0.023 \\
\hline Pers & -0.006 & $-0.103^{*}$ & 0.014 & 0.020 & 0.063 & $-0.109^{*}$ & $0.115^{*}$ & 1 \\
\hline
\end{tabular}

Table (2) reports Pearson (above the diagonal) and Spearman (below the diagonal) correlation coefficients. Spearman correlation shows more significant coefficients, where it is based on ranked, rather than numerical values. The highest significant positive correlation is that between IA and Tobin's Q (0.903 Pearson and 0.94 Spearman, both significant at $1 \%$ level), most probably because the two indicators are calculated using the same variables, market value and book value of firms' equity. According to Pearson coefficients, IA is not significantly correlated to any other of study variables. Whereas, Spearman coefficients show significant correlations between IA and total assets turn over, size, and leverage. 


\section{4-2 Fundamental Analysis}

\section{4-2-1 Firm Value Hypothesis}

\section{Table 3: Outcomes of Regression Analysis for the effect of Intellectual Assets (IA) on Firm Value (Tobin's Q) For the Full Sample}

\begin{tabular}{|c|c|c|c|c|c|}
\hline Variables & $\boldsymbol{\beta}$ & Std. Error & $\mathbf{t}$ & Sig. & VIF (collinearity) \\
\hline Constant & -78.612 & 111.115 & -0.707 & 0.48 & \\
\hline IA & 6.465 & 0.145 & 44.515 & 0.000 & 1.008 \\
\hline Size & 2.457 & 5.633 & 0.436 & 0.663 & 1.019 \\
\hline Growth & -0.00001 & 0.000 & -0.092 & 0.926 & 1.003 \\
\hline Lev & 8.179 & 8.199 & 0.998 & 0.319 & 1.024 \\
\hline Pers & -.051 & 0.862 & -0.59 & 0.953 & 1.005 \\
\hline R-Sq $=\mathbf{8 2 . 3} \%$ & F= 401.6 N=439 & P-value $=\mathbf{0 . 0 0 0}$ \\
\hline
\end{tabular}

Results of regression indicate that the model is statistically significant in elaborating the relationship between intellectual assets and firm value, where $\mathrm{P}$-value turns out to be zero $(<5 \%)$. The variance inflation factors (VIFs) for independent and control variables (all less than 10) free our model from multicollinearity problem. Coefficient determination value ( $\mathrm{R}-\mathrm{Sq}$ ) implies that $82 \%$ of the variations in firm value can be explained through changes in variables contained in the model. Moreover, the intangibles coefficient value (6.465) and significance (0.000) indicate a positive significant impact of intellectual capital on firm value, implying the Acceptance of the first hypothesis.

The above result supports evidence provided by previous studies such as Gamayuni (2015) which reached a positive impact for intellectual capital on firms' value in Indonesia. Also, Maditinos et al (2011) used empirical data from Greek companies listed in the Athens Stock Exchange, and reached the same findings. This was also supported by evidence from Baltic Stock Exchange examined by Berzkalne and Zelgalve (2014). 
The researcher believes that the dramatic increase in market capitalization of Egyptian listed companies would not have been explained by any mean other than the massive growth in intellectual capital, even if such growth is almost centered in one item of intangibles which is brand equity, as argued by Chen (2018).

\section{4-2-2 Firm Liquidity Hypothesis}

\section{Table 4: Outcomes of Regression Analysis for the effect of Intellectual Assets (IA) on Firms' Current Ratio (CR) For the Full Sampl}

\begin{tabular}{|c|c|c|c|c|c|}
\hline Variables & $\boldsymbol{\beta}$ & Std. Error & $\mathbf{t}$ & Sig. & VIF (collinearity) \\
\hline Constant & 13.811 & 2.077 & 6.651 & 0.000 & 1.008 \\
\hline IA & 0.005 & 0.003 & 1.744 & 0.082 & 1.019 \\
\hline Size & -0.567 & 0.105 & -5.388 & 0.000 & 1.003 \\
\hline Growth & 0.0000 & 0.000 & 0.379 & 0.705 & 1.024 \\
\hline Lev & -0.110 & 0.153 & -0.719 & 0.473 & 1.005 \\
\hline Pers & -0.014 & 0.016 & -0.876 & 0.381 & 1.008 \\
\hline R-Sq $=\mathbf{7 . 5 \%}$ & $\mathbf{F}=\mathbf{6 . 9 9 3}$ & $\mathbf{N}=\mathbf{4 3 9}$ & P-value $=\mathbf{0 . 0 0 0}$ \\
\hline
\end{tabular}

Table (3) explores the statistical significance of the model in shaping the relation between intangibles and firms' liquidity; this seems obvious in $\mathrm{P}$-value. However, the model explains only minor variations in current ratio, as indicated by $\mathrm{R}-\mathrm{Sq}(7.5 \%)$. In addition, the coefficient of IA (0.005) is very low indicating a weak impact of IA on CR, yet insignificant (0.082). This leads to the Rejection of the second hypothesis concerning liquidity.

This result corresponds that in Gamayuni (2015), which discards the influence of intangibles on current ratio, where correlation coefficient turned out to be negative and insignificant. A recent study by Demmou et al. (2019) employs intangible assets data of firms operating in developed countries, and suggests that investment in intellectual capital creates a financial friction which places a load on liquidity indicators. 
It is worth mentioning that empirical evidence of other studies supports the opposing direction. For example, Aggelopoulos et al. (2017) reached a positive impact of intellectual assets on firm's liquidity, measured by current ratio, for small-and medium size enterprises in Greece. Also, Kaoru et al. (2017) found a correlation between firms' liquidity and levels of intellectual assets held by a sample of Japanese firms.

The researcher believes that investment in intellectual assets forces firms to employ more cash to finance such investment. This decreases firms' ability to meet its current obligations through current assets.

\section{4-2-3 Firm Activity Hypothesis}

\section{Table 5: Outcomes of Regression Analysis for the effect of Intellectual Assets (IA) on Firms' Total Asset Turn Over (TATO) For the Full Sample}

\begin{tabular}{|c|c|c|c|c|c|}
\hline Variables & $\boldsymbol{\beta}$ & Std. Error & $\mathbf{t}$ & Sig. & VIF (collinearity) \\
\hline Constant & 4.235 & 0.417 & 10.163 & 0.000 & 1.008 \\
\hline IA & 0.001 & 0.001 & 2.099 & 0.036 & 1.019 \\
\hline Size & -0.176 & 0.021 & -8.349 & 0.000 & 1.003 \\
\hline Growth & 0.000 & 0.000 & 0.296 & 0.767 & 1.024 \\
\hline Lev & -0.021 & 0.031 & -0.667 & 0.505 & 1.005 \\
\hline Pers & 0.001 & 0.003 & 0.265 & 0.791 & 1.008 \\
\hline R-Sq = 15\% & $\mathbf{F}=\mathbf{1 5 . 1 6 2}$ & $\mathbf{N}=\mathbf{4 3 9}$ & P-value $=\mathbf{0 . 0 0 0}$ \\
\hline
\end{tabular}

Table (4) indicates the significance of the model $(\mathrm{P}-\mathrm{value}=0)$ in illustrating the relation between intangibles and firms' activity level measured by total assets turnover TATO. R-Sq implies that $15 \%$ of variations in firms' activity level can be justified by independent variables. The sign and significance of IA coefficient (0.001, 0.036) suggest a (weak) positive and significant correlation between IA and TATO. Thus, the third hypothesis is Accepted at 5\% significance level.

Same results are reached by Chen et al. (2005) and Bontis et al (2000). While opposite reached by Gamayuni (2015). The latter found a negative insignificant 
correlation between IA and TATO. Also, Puntillo (2009) failed to show any positive significant association between IA measures and financial performance indicators for Italian firms listed in Milano Stock Exchange.

The researcher believes that since activity level indicators measures the effectiveness of companies in utilizing its resources in generating revenues, therefore, it bears mixed results across firms, industries, and countries. Moreover, the differential selection of study sample and period participates in producing contradictory findings.

\section{4-3 Sensitivity Analysis}

In order to check for the robustness of my results, I perform a sensitivity analysis to investigate the effect of intensity of intangibles on firms' value and financial performance. For this purpose, I split our sample into two sub-samples around the median of IA which turned out to be 0.587 (table (1)):

High-intangibles firms; whose IA is greater than or equal 0.587 , and

Low-intangibles firms; whose IA is less than 0.587 , and re-conduct the regression analyses to test for the three hypotheses as follows:

\section{4-3-1 Firm Value Hypothesis}

Effect of Differential levels of Intangibles on Firm Value

\section{Table 6: Outcomes of Regression Analysis for the effect of Intellectual Assets (IA) on Firm Value (Tobin's Q) For High-Intangibles Firms}

\begin{tabular}{|c|c|c|c|c|c|}
\hline Variables & $\boldsymbol{\beta}$ & Std. Error & $\mathbf{t}$ & Sig. & VIF (collinearity) \\
\hline Constant & -249.194 & 235.934 & -1.056 & 0.292 & \\
\hline IA & 6.603 & 0.210 & 31.47 & 0.000 & 1.005 \\
\hline Size & 9.139 & 11.847 & 0.771 & 0.441 & 1.035 \\
\hline Growth & -0.00002 & 0.000 & -0.184 & 0.854 & 1.003 \\
\hline Lev & 13.84 & 13.027 & 1.062 & 0.289 & 1.021 \\
\hline Pers & 10.115 & 12.793 & 0.791 & 0.430 & 1.024 \\
\hline R-Sq $=\mathbf{8 2 . 4} \%$ & F= 200.087 & $\mathbf{N}=\mathbf{2 1 9}$ & P-value $=\mathbf{0 . 0 0 0}$ \\
\hline
\end{tabular}


The outputs show the significance of the model $(\mathrm{P}$-value $=0)$ in predicting the relation between IA and firm value for high-intangibles firms. R-Sq indicates the ability of IA and control variables in explaining variations in firm value. The coefficient of IA (6.6 significant) is slightly higher than that for full sample (6.465) appearing in table (3).

The significance of IA coefficient implies the Acceptance of our first hypothesis expecting a positive significant impact of IA on Tobin's Q for highintangibles firms.

\section{Table 7: Outcomes of Regression Analysis for the effect of Intellectual Assets (IA) on Firm Value (Tobin's Q) For Low-Intangibles Firms}

\begin{tabular}{|c|c|c|c|c|c|}
\hline Variables & $\boldsymbol{\beta}$ & Std. Error & $\mathbf{t}$ & Sig. & VIF (collinearity) \\
\hline Constant & -1.012 & 0.918 & -1.102 & 0.272 & \\
\hline IA & $\mathbf{3 . 9 1 6}$ & 0.258 & 15.189 & $\mathbf{0 . 0 0 0}$ & 1.062 \\
\hline Size & 0.121 & 0.047 & 2.591 & 0.010 & 1.076 \\
\hline Growth & -0.86 & 0.071 & -1.213 & 0.227 & 1.011 \\
\hline Lev & -0.067 & 0.106 & -0.632 & 0.528 & 1.017 \\
\hline Pers & -0.002 & 0.005 & -0.311 & 0.756 & 1.015 \\
\hline R-Sq $=\mathbf{5 2 . 2 \%}$ & $\mathbf{F}=\mathbf{4 6 . 6 8 3}$ & $\mathbf{N}=\mathbf{2 2 0}$ & P-value $=\mathbf{0 . 0 0 0}$ \\
\hline
\end{tabular}

The low $\mathrm{P}$-value indicates the significance of the model. The explanatory power of the model decreases from $82 \%$ for full sample and high-IA firms to $52 \%$ for low-IA firms, implying that decreasing the intensity of intangibles makes the variable IA less capable of explaining variation in firm value. Additionally, the IA coefficient decreases from above 6 in full sample and high-IA firms to 3.916 in low-IA firms. Yet, the coefficient is still positive and significant so that I Accept the hypothesis of positive impact of IA on firm value for low-intangibles firms.

It is worth noting that same results have been reached by many studies, such as, Chen et al. (2005), Wang (2008 and 2013), Pucci et al. (2013), and Maditinos et al. (2011). 
Therefore, in absolute terms, and regardless of the intensity of investment in intangible assets, the level of intangibles has a positive significant impact on firm value measured by Tobin's $Q$. This conclusion has been proven true from analyzing full sample and the two sub-samples; high-IA firms and low-IA firms.

\section{4-3-2 Firm Liquidity Hypothesis}

Effect of Differential levels of intangibles on Firms' Liquidity:

Table 8: Outcomes of Regression Analysis for the effect of Intellectual Assets (IA) on Current Ratio (CR) For High-Intangibles Firms

\begin{tabular}{|c|c|c|c|c|c|}
\hline Variables & $\boldsymbol{\beta}$ & Std. Error & $\mathbf{t}$ & Sig. & VIF (collinearity) \\
\hline Constant & 11.557 & 2.680 & 4.312 & 0.000 & \\
\hline IA & 0.122 & 0.002 & 1.848 & 0.066 & 1.005 \\
\hline Size & -0.224 & 0.135 & -3.341 & 0.001 & 1.035 \\
\hline Growth & 0.031 & 0.000 & 0.466 & 0.642 & 1.003 \\
\hline Lev & -0.055 & 0.148 & -0.826 & 0.410 & 1.021 \\
\hline Pers & -0.036 & 0.145 & -0.534 & 0.594 & 1.024 \\
\hline R-Sq $=\mathbf{7 . 6 \%}$ & $\mathbf{F = 3 . 4 8 5}$ & $\mathbf{N = 2 1 9}$ & \multicolumn{3}{c|}{ P-value $=\mathbf{0 . 0 0 5}$} \\
\hline
\end{tabular}

Table (8) reports the significance of the model, where $\mathrm{P}$-value $<5 \%$. Almost the same conclusions can be drawn from regression outcomes as that in fundamental analysis in table (4) related to the full sample. The insignificant coefficient of IA $(0.066>5 \%)$ implies the Rejection of the second hypothesis concerning the impact of IA on high-intangibles-firms' liquidity measured by CR.

Table 9: Outcomes of Regression Analysis for the effect of Intellectual Assets (IA) on Current Ratio (CR) For Low-Intangibles Firms

\begin{tabular}{|c|c|c|c|c|c|}
\hline Variables & $\boldsymbol{\beta}$ & Std. Error & $\mathbf{t}$ & Sig. & VIF (collinearity) \\
\hline Constant & 16.135 & 3.317 & 4.865 & 0.000 & \\
\hline IA & -0.035 & 0.931 & -0.517 & 0.606 & 1.062 \\
\hline Size & -0.277 & 0.169 & -4.070 & 0.000 & 1.076 \\
\hline Growth & -0.10 & 0.258 & -0.153 & 0.878 & 1.011 \\
\hline Lev & -0.019 & 0.383 & -0.295 & 0.768 & 1.017 \\
\hline Pers & -0.044 & 0.019 & -0.668 & 0.505 & 1.015 \\
\hline R-Sq = 8\% & $\mathbf{7}$ & $\mathbf{N}=\mathbf{3 . 7 2 2}$ & P-value $=\mathbf{0 . 0 0 3}$ \\
\hline
\end{tabular}


The low P-value points at the model significance. However, the value and insignificance of IA coefficient implies the Rejection of the hypothesis predicting a positive impact of IA on CR, same was concluded in fundamental analysis presented in table (4). Therefore, in absolute terms, and regardless of the intensity of investment in intangible assets, the level of intangibles has no significant impact on firm liquidity measured by current ratio. This conclusion is supported by results of fundamental analysis of full sample and sensitivity analyses of the two sub-samples; high-IA firms and low-IA firms. This result is supported by empirical evidence provided by Gamayuni (2015) and Demmou et al. (2019).

The researcher agrees with the idea that financing intangibles through external funds is somehow constrained, and hence firms rely mainly on internal sources to finance the investment in intangibles; pushing down liquidity indicators.

\section{4-3-3Firm Activity Hypothesis}

Effect of Differential levels of intangibles on Firms' Activity

Table 10: Outcomes of Regression Analysis for the effect of Intellectual Assets (IA) on Total Assets Turn Over (TATO) For High-Intangibles Firms

\begin{tabular}{|c|c|c|c|c|c|}
\hline Variables & $\boldsymbol{\beta}$ & Std. Error & $\mathbf{t}$ & Sig. & VIF (collinearity) \\
\hline Constant & 3.025 & 0.668 & 4.525 & 0.000 & \\
\hline IA & 0.084 & 0.001 & 1.264 & 0.208 & 1.005 \\
\hline Size & -0.222 & 0.034 & -3.291 & 0.001 & 1.035 \\
\hline Growth & 0.026 & 0.000 & 0.395 & 0.693 & 1.003 \\
\hline Lev & -0.057 & 0.037 & -0.852 & 0.395 & 1.021 \\
\hline Pers & -0.023 & 0.036 & -0.338 & 0.736 & 1.024 \\
\hline R-Sq $=\mathbf{6 . 5 \%}$ & $\mathbf{F}=\mathbf{2 . 9 6 8}$ & $\mathbf{N}=\mathbf{2 1 9}$ & P-value $=\mathbf{0 . 0 1 3}$ \\
\hline
\end{tabular}

Results show the significance of the model $(\mathrm{P}$-value $=0.013)$ in predicting the relation between IA and high-IA firms' activity level. Whereas, the insignificance of IA coefficient $(0.208>5 \%)$ Rejects the hypothesis of a positive impact of IA on TATO for high-IA firms. This result differs from that in fundamental 
analysis of full sample presented in table (5). The fundamental analysis accepts the hypothesis of such positive impact.

\section{Table 11: Outcomes of Regression Analysis for the effect of Intellectual Assets (IA) on Total Assets Turn Over (TATO) For Low-Intangibles Firms}

\begin{tabular}{|c|c|c|c|c|c|}
\hline Variables & $\boldsymbol{\beta}$ & Std. Error & $\mathbf{t}$ & Sig. & VIF (collinearity) \\
\hline Constant & 5.545 & 0.517 & 10.715 & 0.000 & \\
\hline IA & 0.026 & 0.145 & 0.449 & 0.654 & 1.062 \\
\hline Size & -0.549 & 0.026 & -9.46 & 0.000 & 1.076 \\
\hline Growth & 0.195 & -0.04 & 3.473 & 0.001 & 1.011 \\
\hline Lev & -0.045 & 0.060 & -0.794 & 0.428 & 1.017 \\
\hline Pers & 0.027 & 0.003 & 0.487 & 0.626 & 1.015 \\
\hline R-Sq $=\mathbf{3 0} \%$ & $\mathbf{F}=\mathbf{2 1 . 1 3 5}$ & $\mathbf{N}=\mathbf{2 2 0}$ & P-value $=\mathbf{0 . 0 0 0}$ \\
\hline
\end{tabular}

Table (11) points at the significance of the model, where $\mathrm{P}$-value equals 0. The insignificance of IA coefficient $(0.654>5 \%)$ implies no impact of IA on lowIA firms' activity level. Thus, I Reject the hypothesis predicting a positive impact of IA on TATO for low-IA firms. Again, this result contradicts fundamental analysis of full sample which supports such positive impact.

Therefore, on the aggregate level, and according to our fundamental analysis, the hypothesis of positive impact of IA on firms' activity level is supported. However, this conclusion is not valid at high and low-IA firm levels.

Empirical results of Bontis et al. (2000), and Puntillo (2009) support my results. The researcher believes the justification is that firms' activity indicators assess how much pounds invested in total assets is translated into revenues. Undeniable is the fact that investment in intangibles is long term investment which takes time period to show its fruits, reflected in higher revenues and more profits. 


\section{4-4 Testing for Mean Differences}

As a further robustness analysis, I conduct a T-Test for mean differences between the two sub-samples: high-IA firms and low-IA firms. The results are presented in the following table:

\section{Table :12 Independent Samples Test}

\begin{tabular}{|c|c|c|c|}
\hline IA & $\begin{array}{c}\text { High-Intangibles } \\
\text { Firms }\end{array}$ & $\begin{array}{c}\text { Low-Intangibles } \\
\text { Firms }\end{array}$ & $\begin{array}{c}\text { Differences } \\
(\text { Sig })\end{array}$ \\
\hline Tobin's Q & 136.1559 & 0.1233 & $\begin{array}{c}29.7037 \\
(0.000)^{*}\end{array}$ \\
\hline CR & 2.6117 & 1.7876 & $\begin{array}{c}134.3682 \\
(0.000)^{*}\end{array}$ \\
\hline TATO & 0.8356 & 2.6049 & $\begin{array}{c}0.0068 \\
(0.983)\end{array}$ \\
\hline Size & 19.8749 & 0.7059 & $\begin{array}{c}0.1297 \\
(0.048)^{*}\end{array}$ \\
\hline Growth & -0.02197 & 19.5068 & $\begin{array}{c}0.3681 \\
(0.009)^{*}\end{array}$ \\
\hline Lev & 0.6196 & 0.00371 & -0.02569 \\
& & 0.33344 & $\begin{array}{c}0.2861 \\
(0.003)^{*}\end{array}$ \\
\hline Pers & 0.06932 & -0.6531 & $\begin{array}{c}0.72252 \\
(0.421)\end{array}$ \\
\hline
\end{tabular}

*Significant at $5 \%$ significance level

Results of T-Test imply that the two sub-samples have significantly different means with respect to IA (by definition, since the sample was split originally around IA median), Tobin's Q, TATO as main variables. Also, the means are significantly different with respect to size and leverage as control variables. The means are not significantly different with respect to $\mathrm{CR}$ as a main variable, and growth and persistence as control variables. 
This further supports study's evidence of accepting the first and third hypotheses predicting a significant impact of intangibles on both firm value and firm activity levels, and rejecting the second hypothesis predicting an impact of IA on firm liquidity levels.

\section{5 - SUMMARY AND CONCLUSION}

This study attempted to evaluate the role of intellectual capital in financial markets. I investigate the impact of intellectual assets on firm value and firm performance for a sample of Egyptian firms continuously listed on the Egyptian stock exchange during the period from 2000-2014. Based on the reasoning that intangibles have been perceived by literature as the value driver of firms' competitive advantage, research hypotheses predict that investment in intellectual capital has a positive significant impact on firm value and performance. I assess firm value through Tobin's $Q$, whereas for performance, two measures were selected; current ratio denoting firm's liquidity and total assets turn over denoting firm's activity.

Two levels of analyses were conducted: fundamental and sensitivity analysis. First, I regresses intellectual assets on measures of firm value and financial performance for the full sample (aggregate level). Second, the full sample was divided according to intangibles intensity into two sub-samples: high-intangibles firms and low-intangibles firms, and regression analysis was re-conducted (partial level).

\section{Conclusions}

The first hypothesis predicts a positive impact of intellectual capital on firm's value. This hypothesis has been supported by empirical evidence; both at the aggregate and partial levels. That is, investment in intangible assets shows a significant impact on Tobin's Q for the full sample and the two sub-samples: high and low-intangibles firms. Evidence is consistent with the premise that the higher the intangible assets owned by the company, the more appreciation investors will assign to that company, where they link such investment to profitability and sus- 
tainability. The same findings were reached by a number of studies. Chen et al. (2005), Shui (2006), Wang (2008), and Pucci et al. (2013), while employing different measures and using different contexts; they all reached a positive direct relationship between intangibles measures and firm value. It is worth mentioning that other studies discard any impact of intangibles on corporate value, for example, Ferraro and Veltri (2011), and Mehralian et al. (2012).

The second hypothesis predicts a positive impact of intellectual capital on firm's liquidity level as an indicator of financial performance. For liquidity, measured by current ratio, the hypothesis has been rejected, both at the aggregate and partial levels. Results failed to support any significant impact of intangibles on firm's liquidity, neither for the full sample nor for the two sub-samples. The researcher believes that the reason is that investment in intangible assets at all levels represents a financial burden on firms' availability of cash, where resources are devoted for financing these investments. This finding is supported by some studies and contradicted by others. Gamayuni (2015) and Demmou et al. (2019) provide evidence of insignificant impact of intangibles on firm's liquidity, whereas, Aggelopoulos et al. (2017) and Kaoru et al. (2017) provide opposing evidence.

The third hypothesis predicts a positive impact of intellectual capital on firm's activity level as another indicator of financial performance. With respect to firm's activity, measured by total assets turn over; study's results differ on the aggregate level and partial levels. For the full sample, results support the positive significant impact of intangibles on total assets turn over. For high- and lowintangibles firms, results fail to support such hypothesis. Similarly, Bontis et al. (2000), and Bollen et al. (2005) suggest a positive relationship between intangibles and firm performance. While Firer and Williams (2003), and Maditinos et al. (2011) provided evidence rejecting such relation.

This paper contributes to the body of literature addressing the impact on intellectual capital on firms' different dimensions. Examining the Egyptian setting which is socially, economically, and politically different from other countries, I analyze how would investment in intangible assets impact firm's value and finan- 
cial performance. Results support the national trend towards enhancing investment in knowledge-based and technology-based projects. Increasing investments in innovative creational schemes would push up firms' value and performance.

\section{Recommendations}

The evidence provided by this paper has important insights. First, for companies, investing in intellectual assets is worthwhile since it paves the way for gaining competitive advantages and market appreciation. The most successful corporations nowadays are the ones that intensively invest in knowledge-based assets. We can see the outstanding success and superior profits of international companies like Google, Microsoft, Facebook, and Twitter are mainly based on intangibles, while traditional assets play only a marginal role. Second, for standard setters, accounting treatment for intellectual assets should be reformulated in a way that it considers the special nature and characteristics of these assets. Assets with different levels of uncertainty should be weighted differentially in the financial statements. Third, for researchers, advanced proxies should be developed for assessing firm's performance especially in case of intangiblesintensive companies. Existing evidence on intellectual capital's impact on firms' financial performance is mostly circumstantial and often contradictory. This supports the argument that traditional measures of a company's performance may be unsuitable in the knowledge-based economy driven by intellectual capital. Fourth, for policymakers, in a rapid-growing technology world, sound economic development would not be enhanced without intensive investment in knowledge-based projects. Supportive mechanisms should be directed towards innovations and creativity. Projects based on knowledge and technology should be incubated and supported financially and structurally on the national level.

\section{Future Research}

The researcher believes that the topic of this paper remains interesting and open. Further research could be conducted using different proxies for independent and dependent variables. For example, intangible assets can be assessed 
through incorporating R\&D expenses and advertising expenses, or through calculating the value added intellectual coefficient VAIC. Also, firm value and financial performance can be measured through other metrics. A promising area for future research is to develop new performance indicators capable of emphasizing the nature of intangibles. Moreover, researchers would propose how intellectual assets be better presented in financial statements in a way that considers its uncertain nature.

\section{References}

Aggelopoulos, E. (2017). What explains changes in accounting divisional performance under liquidity shortage conditions? Evidence from the Greek Banking. Journal of Accounting and Management Information Systems 16(1): 89-106.

Alves, S. and J. Martins. (2014). The impact of intangible assets on financial and governance policies: A simultaneous equation analysis. Journal of Applied Finance and Banking 4(1): 61-89.

Appuhami, R. (2007). The impact of intellectual capital on investors' capital gains on shares: An empirical investigation of Thai banking, finance, and insurance sector. International Management Review 3(2): 23-39.

Baldwin, J.R., W. Gu and R. Macdonald. (2012). Intangible Capital and Productivity Growth in Canada. Statistics Canada Catalogue No. 15-206X, The Canadian Productivity Review. No. 29.

Barron, O.E., Byard, D., Kile, C. and Riedl, E.J., (2002). High-technology intangibles and analysts' forecasts. Journal of Accounting Research, 40(2): 289-312.

Barth, M., R. Kasznik and M. McNichols. (2001). Analyst Coverage and

Intangible Assets. Journal of Accounting Research 39(1): 1-34. 
Berzkalne, I., and E. Zelgalve. (2014). Intellectual capital and company value. Procedia-Social and Behavioral Sciences 110: 887-896.

Bollen, L., P. Vergauwen, and S. Schnieders. (2005). Linking intellectual capital and intellectual property to company performance. Management Decision 43(9):1165-1185.

Bontis, N. (2001). Assessing knowledge assets: A review of the models used to measure intellectual capital. International Journal of Management Review $3(1): 41-60$.

Bontis, N., W.C. Chong Keow, and S. Richardson. (2000). Intellectual capital and business performance in Malaysian industries. Journal of intellectual capital 1(1):85-100.

Cabral, L. (2000), Introduction to Industrial Organization (Cambridge, MA: MIT Press). Christensen,

Chalmers, K., G. Clinch, J.M. Godfrey, and Z. Wei. (2012). Intangible assets, IFRS and analysts' earnings forecasts. Accounting and Finance 52: 691-721.

Chang, W. S. (2013). Are R\&D and intellectual property rights related to the firm's financial performance? The perspectives on intellectual capital. International Journal of Technology, Policy and Management 13: 245-260.

Chen, W. (2018). A comparative study of intangible investment in Egypt and South Africa. Journal of Intellectual Capital 19 (3): 487-497.

Chen, M., S. Cheng, Y. Hwang. (2005). An empirical investigation of the relationship between intellectual capital and firms' market value and financial performance. Journal of Intellectual Capital 6(2): 159-176.

Choi, W.W., Kwon, S.S. and Lobo, G.J., 2000. Market valuation of intangible assets. Journal of Business Research, 49(1): 35-45. 
Cohen,W. M., R. R. Nelson and J. P.Walsh. (2000). Protecting their intellectual assets: Appropriability conditions and why U.S. manufacturing firms patent (or not). NBERWorking Paper No. 7552.

Corrado, C. and C. Hulten. (2014). Innovation accounting: Measuring Economic Sustainability and Progress, University of Chicago Press. Chicago, IL.Corrado, C., C. Hulten, and D. Sichel. (2005), Measuring Capital and Technology: An Expanded Framework, University of Chicago Press. Chicago, IL.11-46.

Corrado, C., C. Hulten, and D. Sichel. (2009). Intangible capital and US economic growth. Review of Income and Wealth 55(3): 661-685.

Demmou, L., I. Stefanescu, and A. Arquie. (2019). Productivity growth and finance: The role of intangible assets-a sector level analysis. Working paper. Available at www.ssrn.com

Edvinsson, L. (1997). Developing intellectual capital at Skandia. Long Range Planning 30(3): 366-373.

Edvinsson, L., and M.S. Malone. (1997). Intellectual capital: Realizing your company's true value by finding its hidden brainpower. Harper Business, New York, NY.

Ferraro, O., and S. Veltri. (2011). The Value Relevance of Intellectual Capital on the Firm's Market Value: An Empirical Survey on the Italian Listed Firms. International Journal of Knowledge-Based Development 2: 66-84.

Firer, S. and M. Williams. (2003). Intellectual capital and traditional measures of corporate performance. Journal of intellectual Capital 4(3):348-360.

Fukao, K., T. Miyagawa, K. Mukai, Y. Shinoda, and K. Tonogi. (2009). Intangible investment in Japan: Measurement and contribution to economic growth. Review of Income and Wealth 55(3): 717-736. 
Gamayuni, R.R. (2015). The effect of intangible asset, financial performance and financial policies on the firm value. International Journal of Scientific and Technology Research 4(1): 202-212.

Gu, F. and W. Wang. (2005). Intangible assets, information complexity, and analysts' earnings forecasts. Journal of Business Finance \& Accounting, 32(9-10): 1673-1702.

Hao, Janet Xiaohui, Manole, V. and Van Ark, B. (2009). "Intangible Capital and Growth - an International Comparison", European Commission within the Seventh Framework Programme.

International Financial Reporting Standards. (2016). IAS 38 Intangible assets. Available at: www.ifrs.org.

Ismail, T. H. (2011). Intellectual capital reporting in knowledge economy of Egypt. International Journal of Critical Accounting 3(2-3): 293-317

Kaoru, H., M. Daisuke, and T. Miho. (2017). Intangible assets and firm's liquidity holdings: Evidence from Japan. RIETI research project.

Kaplan, R.S. and D.P. Norton. (2004). Strategy Maps - Converting Intangible Assets into Tangible Outcomes. Harvard Business School Press, Boston, MA.

Lang, L. H., and R. M. Stulz. (1994). Tobin's q, corporate diversification, and firm performance. Journal of political economy, 102(6), 1248-1280.

Lev, B. (2001). Intangibles: Management, measurement, and reporting. Brookings Institution Press, Washington, DC.

Lev, B. (2003). Remarks on the measurement, valuation, and reporting of intangible assets. FRBNY Economic Policy Review.

Maditinos, D., D. Chatzoudes, C. Tsairidis, and G. Theriou. (2011). The impact of intellectual capital on firms' market value and financial performance. Journal of Intellectual Capital 12(1): 132-151. 
Marrano, M.G., J. Haskel, and G. Wallis. (2009). What happened to the knowledge economy? ICT. Intangible investment, and Britain's productivity record revisited. Review of Income and Wealth 55(3): 686-716.

Masayuki. M, (2012). Credit Constraints in Intangible Investment. Discussion Papers (Japanese) 12016, Research Institute of Economy, Trade and Industry (RIETI).

Mehralian, G., H. R. Rasekh, P. Akhavan, and M.R. Sadeh. (2012). The Impact of Intellectual Capital Efficiency on Market Value: An Empirical Study from Iranian Pharmaceutical Companies. Iranian Journal of Pharmaceutical Research 11: 195-207.

Mouritsen, J., H. Larsen, and P. Bukh. (2001). Intellectual capital and the "capable firm": Narrating, visualizing and numbering for managing knowledge. Accounting Organizations and Society 26 (7-8): 735-762.

OECD (1992). OECD proposed guidelines for collecting and interpreting technological innovation data., olso Manual, Paris.

OECD (2013). Supporting Investment in Knowledge Capital, Growth and Innovation, OECD Publishing, Paris.

Pucci, T., C. Simoni, and L. Zanni. (2013). Measuring the relationship between marketing assets, intellectual capital and firm performance. Journal of Management and Governance 2(4): 1-28.

Pulic, A. (2000a). VAIC-An accounting tool for IC management. International Journal of Technology Management 20(5-7): 702-714.

Puntillo, P. (2009). Intellectual capital and business performance. Evidence from Italian banking industry. Electronic Journal of Corporate Finance 4(12): 97-115. 
Riahi-Belkaoui, A. (2003). Intellectual capital and firm performance of US multinational firms: A study of the resource-based and stakeholders views. Journal of Intellectual Capital 4(2): 215-226.

Shiu, H.J. (2006b). The application of the value added intellectual coefficient to measure corporate performance: Evidence from technological firms. International Journal of Management 23(2): 356-365.

Stewart, T. (1997). The new wealth of organizations. Doubleday, New York, NY

Tan, H.P., D. Plowman, and P. Hancock. (2007). Intellectual capital and financial returns of companies. Journal of Intellectual capital 8(1): 76-95.

Ting, I.W.K., and H. H. Lean. (2009). Intellectual capital performance of financial institutions in Malaysia. Journal of Intellectual capital 10(4): 585-608.

Wang, J. (2008). Investigating Market Value and Intellectual Capital for S\&P 500. Journal of Intellectual Capital 9: 546-563.

Wang, M. (2013). Value Relevance on Intellectual Capital Valuation Methods: the Role of Corporate Governance. Quality \& Quantity 47: 1213-1223

Yallwe, A., and A. Buscemi. (2014). An era of intangible assets. Journal of Applied Finance and Banking 4(5):17-26.

Yang, C., and Y. Lin. (2009). Does intellectual capital mediate the relationship between HRM and organizational performance? Perspective of a healthcare industry in Taiwan. International Journal of Human Resource Management 20 (9): 1965-1984. 
